\title{
Exploring life as we don't yet know it
}

Media coverage of genetics research, and scientists' responses to it, tend to have a short-term perspective. But enough is now foreseeable for longer-term thinking about the impact on society to be more developed, and to have a higher profile.

Some scientists whose work gets taken up by the media can find subsequent research something of an anticlimax. Others may look forward to the peace and quiet. The latter may well include the authors of a publication in last week's issue of a letter reporting the cloning of sheep (Nature 380, 64; 1996), which was followed in some countries by voluminous media coverage, reverberating (at least in the United Kingdom) for days. What was noticeable, among much predictable comment (both for and against such research), was that even the most sympathetic commentators appeared to have no choice but to leave readers with a sense of unease as to where genetics is taking us.

There is a response to such issues (to which scientists are too often prone) that points to a combination of regulations and technical obstacles as a way of allaying fears. That is surely too shortsighted. When issues of international scientific and commercial competitiveness are at stake, national regulations on research and its applications may present only a flimsy barrier. And as for technical obstacles, the history of the determined imaginations of scientists suggests that, where no fundamental law is being broken, those hindrances will often be shorter lived than people expect.

That the growing power of molecular genetics confronts us with future prospects of being able to change the nature of our species is a fact that seldom appears to be addressed in depth. Scientific knowledge may not yet permit detailed understanding, but the possibilities are clear enough. This gives rise to issues that in the end will have to be related to people within the social and ethical environments in which they live, but which, sooner than that, should be considered and analysed in a more detached and percipient fashion. And the agenda is set by mankind as a whole, not by the subset involved in the science.

Attempts to involve both scientists and the public in debates on genetics have varied in their success, but are at any rate inadequate so far. Involving laypeople in grant funding (as happens in the United States), and holding "consensus conferences" (as has happened occasionally in the United Kingdom and Scandinavia), is only a scratch at the surface, albeit developing an important principle. And although religious organizations, legislative bodies and others have provided many documents on the impact of genetics on society, these have often been limited by their particular agendas.

There is a need also for an international body that can stand back a little. The Unesco International Bioethics Committee (IBC) is pursuing such a role. It also has a potentially significant part to play in enhancing public understanding of the issues. Although Unesco's reputation is questioned in some countries, the bioethics committee has no vested interest in the outcome of its deliberations and demonstrably has enough pulling power to attract the involvement of the appropriate individuals. Importantly, it has no regulatory power, and no direct influence on the future of research. Even more importantly, it recognizes that responsibility for these issues spreads much wider than the scientific community.

The task of such a body should be to explore, preferably well ahead of their possible achievement, aspects of foreseeable 'brave new worlds', in both the optimistic and the ironic sense. At the least it can provide an additional touchstone for those thinking in national regulatory contexts about the implications of developments in genetics as they happen, as well as for opponents and promoters of research.

Is the IBC looking far enough ahead? Gene therapy, human biodiversity and the implications of such research for different parts of the globe have appropriately figured high on its agenda, but have been predictable issues for some time - they are now the immediate problems. But the IBC or some other body could be doing us all a service, although courting controversy, by extrapolating some years into the future and examining scenarios in which 'improvements' to the genome that are currently regarded as out of bounds have become both practicable and, to some, eminently desirable. Such a programme will not resolve conflicts (far from it) but will usefully prepare the ground for debates to come.

\section{Science in American Life}

Scientists have been over-sensitive to public discussion of what they do.

THE American Chemical Society (ACS) will this week give up its battle with the Smithsonian Institution to revise a popular exhibition for which the society paid $\$ 5.3$ million, but which it came to despise (see page 95).

The Science in American Life exhibition will continue indefinitely at the National Museum of American History in Washington DC, with the ACS powerless to strip it of the politically correct elements that so angered some society members. These elements include a gloomy portrayal of the Manhattan Project to develop the atomic bomb, and an amusing if somewhat stilted portrayal of Victorian chemists, in the laboratory, arguing about intellectual property rights.

When the ACS agreed to pay the Smithsonian to mount the exhibition, it seems to have anticipated a 'dog and pony show' in which science's impressive achievements would be paraded before a suitably impressed public. When it saw what it was getting, it accused the curators of historical "revisionism" and fought hard for changes.

The society was naive to expect any such thing. Science museums are already awash with 'boosterism'. (Across the Mall, at the Air and Space Museum, the visitor will look in vain for any serious discussion of the nature of the NASA beast.) The curators of the Science in American Life exhibition were social historians, professionally obliged to identify important questions about their subject matter - as they have done.

The show is flawed in some regards: it makes errors of omission, and it does not look as though it is worth $\$ 5.3$ million. But the only reason it has drawn such criticism from scientific societies is that they are going through a sensitive phase, in which public support for science funding is less assured than in the recent past. A more self-assured community would have taken the exhibition in its stride, recognizing that public discussion of the place of science in society is not only inevitable, but desirable. 